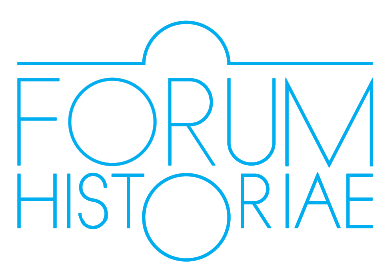

\title{
Od kampaní proti „židobol'ševizmu“ k návrhom na „riešenie židovskej otázky“. Antisemitizmus v publicistike Karola Körpera v druhej polovici 30. rokov 20. storočia*
}

\author{
Miloslav Szabó
}

\begin{abstract}
:
SZABÓ, Miloslav: From Campaigns against "Judeo-Bolshevism" to Proposals for the Solution of the "Jewish Question". Anti-Semitism in the Journalism of Karol Körper from the Second Half of the 1930s.

This article examines the effects of anti-Semitism on the journalism of Karol Körper. Karol Körper was a Catholic priest and a politician within Hlinka's Slovak People's Party from about 1935 to the early 1940s. Specifically, the article follows the formation of anti-Semitism conspiracies provoked by campaigns against "Judeo-Bolshevism" that resulted in proposal for the resolution of the so-called Jewish question from 1936-1938. It further shows how these tendencies contributed to Körper's Fascist radicalism which was not only based on anti-Semitism but also on the cult of personality and political martyrdom. Körper especially developed these ideas while in the position of the main cleric in Hlinka's Guard in 1939 and 1940.
\end{abstract}

Keywords: Anti-Semitism, Fascism, Hlinka's Slovak People’s Party, Karol Körper, Catholicism, Cult of Personality, Martyrdom

DOI: https://doi.org/10.31577/forhist.2019.13.1.5

A ntisemitizmus na Slovensku v rokoch predchádzajúcich vyhláseniu autonómie na jeseň 1938 doteraz nebol predmetom komplexného historického výskumu. Jedným z dôvodov tohto stavu je fakt, že politický systém a realita právneho štátu počas predmníchovskej Československej republiky neumožňovali otvorenú diskrimináciu židovskej menšiny. Ojedinelé protižidovské útoky mali na svedomí zväčša prívrženci Národnej obce fašistickej. ${ }^{1}$ Antisemitizmus sa však dostával do popredia i v propagande Hlinkovej slovenskej l'udovej strany (HSL'S). Zásadný zlom predstavoval medzinárodný kontext, predovšetkým vojenský pakt Československa so Sovietskym zväzom, prijatie protižidovskej legislatívy a prenasledovanie Židov v nacistickom Nemecku a vypuknutie občianskej vojny v Španielsku v roku 1936. Všetko to malo za následok oživenie stereotypu „židovského bol’ševizmu“, ktorý sa rozvíjal už bezprostredne po prvej svetovej vojne a nadväzoval na útoky antisemitov proti liberalizmu a socializmu z prelomu 19. a 20. storočia. ${ }^{2}$

\footnotetext{
* Štúdia bola vypracovaná v rámci projektu SASPRO, č. 00079/01/03: Antisemitizmus na medzivojnovom Slovensku a v Rakúsku (1918 - 1938).

1 SZABÓ, Miloslav. Auf dem Weg zum Holocaust? Der slowakische Antisemitismus in der Ersten Tschechoslowakischen Republik. In S:I.M.O.N. - Shoah: Intervention. Methods. Documentation, 2015, roč. 2, č. 1, s. 11-24. Dostupné na internete: http://simon.vwi.ac.at/images/Documents/Articles/2015-2/2015-2_ ART_Szabo/ART_Szabo01.pdf.

2 SZABÓ, Miloslav. Od slov k činom. Slovenské národné hnutie a antisemitizmus (1875 - 1922). Bratislava :
} 
V tejto súvislosti sa v historiografii spomína jednak deklarácia z tzv. pieštanského zjazdu HSL'S v júli 1936, kde sa volá po spolupráci s krestanskými národmi, a nie s „medzinárodnými reprezentantmi materialistickej ideológie a židobol’ševickej anarchie a $^{\text {a }}$ a jednak vystúpenie poslanca HSLSS Karola Sidora v zahraničnom výbore československého parlamentu v roku 1937, v ktorom žiadal vystahovat' Židov do sovietskej autonómnej oblasti Birobidžan na Ďalekom východe.

Čo predchádzalo obviňovaniu Židov zo šírenia bol’ševizmu v druhej polovici 30. rokov? Na začiatku stáli útoky proti komunistickej tlači, ktorá poslúžila ako projekčná plocha na antisemitské obviňovanie. Na jar roku 1936 vyšla v komunistickom L'udovom denníku polemika z pera mladého komunistu židovského pôvodu Eugena Klingera, ktorý sa pod dojmom udalostí v Španielsku, kde revolučná vláda zahájila antiklerikálnu kampaň, nepriamo vyhrážal smrtou vodcovi HSL'S Andrejovi Hlinkovi. ${ }^{4}$ Tlačové orgány HSL'S si pri referovaní o občianskej vojne v Španielsku všímali takmer výlučne obete z radov kléru a podobne ako náboženská a nacionalistická pravica v iných krajinách aj l’udáci zneužili španielske udalosti na rozpútanie antisemitskej propagandy, ked’že za terorom španielskych revolucionárov odhalovali celosvetové židovské sprisahanie. ${ }^{5}$ Šéfredaktor novín HSL'S Slovák Karol Sidor odštartoval agresívnu kampaň proti Židom a potom, čo mu úvodník v Slovákovi skonfiškovala cenzúra, predniesol ho v rámci interpelácie ministra vnútra v parlamente. ${ }^{6}$ Do debaty sa zapojil aj Andrej Hlinka, ktorý obhajoval demonštrácie študentov z katolíckeho internátu Svoradov proti uvádzaniu filmu Golem v bratislavských kinách.7 Tie nasledovali po Sidorovej interpelácii a koncom apríla 1936 po niekol’ko dní obmedzovali život v meste. Ich organizátori sa očividne inšpirovali protestmi nemeckých a rakúskych nacistov proti premietaniu amerického filmu Na Západe nič nové niekol'ko rokov predtým. ${ }^{8}$ Táto, na slovenské pomery nevídaná antisemitská kampaň, pokračovala pod pláštikom boja proti „židobol’ševizmu“ na stránkach l'udáckych novín Slovák a Slovenská pravda a neutíchla do jesene 1938.

Jedným z najaktívnejších protagonistov tejto kampane bol katolícky kňaz, kanonik Karol Körper, ktorý popri cirkevných aktivitách už od 20. rokov koketoval s politikou. ${ }^{9}$ Körper pochádzal z rodiny uhorského colníka pôvodom z Burgenlandu,

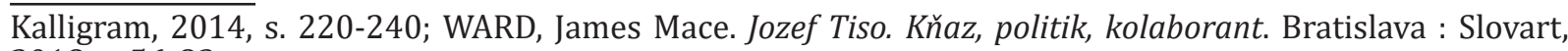
2018, s. 56-83.

3 Cit. podl'a ARPÁŠ, Róbert. Piešt’anský zjazd ako medzník na ceste HSL’S k totalite. In Človek a spoločnost', 2004 , roč. 7 , č. 3, s. 166. Dostupné na internete: http://www.clovekaspolocnost.sk/jquery/pdf. php?gui=WE67FX5TIH8G9JMNGUXS894.

4 Pozri WARD 2018, s. 171.

5 Pozri GRIECH-POLLELE, Beth A. The Impact of the Spanish Civil War upon Roman Catholic Clergy in Nazi Germany. In SPICER, Kevin (ed.) Antisemitism, Christian Ambivalence, and the Holocaust. Bloomington : Indiana University Press, 2007, s. 121-135.

6 SIDOR, Karol. Na margo jednej interpelácie. In Slovák, roč. 18, č. 95, 24. apríla 1936, s. 1.

7 HLINKA, Andrej. Semitská vd’aka. In Slovák, roč. 18, č. 99, 29. apríla 1936, s. 1.

8 Pozri SZABÓ, Miloslav. From Protests to the Ban. Demonstrations against the „Jewish“ Films in Interwar Vienna and Bratislava. In Journal of Contemporary History, 2019, roč. 54, č. 1, s. 5-29.

9 Informácie o živote Karola Körpera historici zväčša čerpajú z jeho spomienok napísaných v 70. rokoch minulého storočia, ale uverejnených až v roku 1993. Podobne ako vo svojej obhajobe pred Národným súdom v roku 1946, aj v tomto texte sa Körper snaží zbavit’ zodpovednosti, zamlčuje svoj podiel na šírení protižidovskej propagandy a zdôrazňuje svoju rolu záchrancu Zidov. KÖRPER-ZRÍNSKY, Karol. Môj život. 
po matke mal byt' potomkom vedlajšej vetvy rodu Zrínskych, čo zistil až dodatočne, ked' ako poslanec slovenského snemu musel dokazovat' „árijský“" pôvod. ${ }^{10}$ S otcom mal asi zložitý vzt’ah, ešte v spomienkach zo 60. rokov minulého storočia mu napr. vyčítal filosemitizmus, lebo vd'aka svojej profesii bol často v kontakte so židovskými držitel'mi výčapných licencií a cenil si ich podnikatel'skú zdatnost' a vzdelanie. Körper preto musel navštevovat' židovskú školu. ${ }^{11}$ Neskôr sa dostal do prestížneho budapeštianskeho teologického seminára. Slovenské národné povedomie si Körper osvojil až po prvej svetovej vojne a ako mnohí iní kňazi, aj on sa začal angažovat' v HSL'S, navyše sa už v 20. rokoch stal členom fašistického polovojenského zoskupenia Rodobrana napojeného na HSL'S. Zakladatel' a organizátor Rodobrany Vojtech Tuka vštepoval rodobrancom kvázi mystický kult mučeníkov, ${ }^{12}$ čo malo akiste vplyv na mladých politizujúcich kňazov ako Körper či neskorší popredný politik HSL’S Anton Šalát. ${ }^{13} \mathrm{~V}$ decembri 1938 bol Körper zvolený za poslanca Snemu Slovenskej krajiny a počas celého trvania slovenského štátu zostal aj poslancom slovenského snemu. Bol vymenovaný za vysokého úradníka na ministerstve školstva a národnej osvety, kde predsedal tzv. cirkevnému odboru, okrem toho členom mnohých predstavenstiev a dozorných rád. $\mathrm{V}$ roku 1939 sa stal hlavným duchovným správcom Hlinkovej gardy, odkial' ho však po salzburských rokovaniach v lete 1940 vytlačil nacistický poradca Viktor Nageler. Körper napriek tomu neprestal oslavovat' Hitlera a nemeckú armádu a až porážka nemeckej armády pri Stalingrade ho donútila, aby sa publicisticky odmlčal. Po potlačení povstania na jeseň 1944 mu pripadla nevd’ačná úloha zaujat’ k nemu v slovenskom sneme postoj, ktorý však nemeckú stranu neuspokojil.

\section{Vierovyznanie alebo rasa? Protižidovské stereotypy v Körperovej publi- cistike v rokoch 1936 až 1938}

Vrát'me sa však do druhej polovice 30. rokov. Posledné parlamentné vol'by v ČSR, zmluva so Sovietskymi zväzom a občianska vojna v Španielsku - to všetko prehíbilo pokušenie z politiky, ktoré Karol Körper a mnohí d'alší slovenskí kňazi pocitovali už dávno predtým. Možnost' realizácie sa Körperovi naskytla na jar roku 1936, ked' sa HSL’S rozhodla svoj dovtedajší východoslovenský týždenník Slovenská pravda vydávat' ako - popri Slovákovi - druhý, tzv. grajciarový denník s neustále sa zvyšujúcim nákladom. Šéfredaktorom sa stal ambiciózny Alexander Mach a Körper sa podujal písat' úvodníky. ${ }^{14}$ Aktívny bratislavský kanonik napísal pod značkou Dr. k. k. v rokoch 1936 až 1939 do Slovenskej pravdy okolo tisíc úvodníkov na najrozmanitejšie témy, ale vždy s politickým posolstvom v duchu

\footnotetext{
Bratislava : Lúč, 1993. V nedávno publikovanom životopisnom náčrte Karola Körpera, ktorý ako vôbec prvý vychádza z dostupných historických prameňov, sa jeho antisemitizmus vôbec nespomína. Pozri KÁRPÁTY, Vojtech. Vae victis! Zo života Karola Körpera. In Kultúra, 2017, roč. 20, č. 20, s. 4-5; 2017, roč. 20, č. 21, s. 4-5; 2018, roč. 21 , č. 1 , s. $10-11$.

10 Materiály sa nachádzajú v neusporiadanom osobnom fonde Karola Körpera v Slovenskom národnom archíve.

11 KÖRPER-ZRÍNSKY 1993, s. 19.

12 HRUBOŇ, Anton. Alexander Mach. Radikál z povolania. Bratislava : Premedia, 2018, s. 51-61.

13 ŠALÁT, Anton. Rodobranecké rozpomienky. In Štúrov hlas, roč. 3, č. 11, 14. marca 1941, s. 5.

14 HRUBOŇ 2018, s. 124-126.
} 
HSLS. Tieto texty tvorili po druhej svetovej vojne jeden z hlavných bodov obžaloby z vlastizrady pred Národným súdom, hoci Körper si na nich práve naopak budoval svoju obhajobu. To naznačuje, že obe strany postupovali selektívne: zatial' čo žaloba sa snažila nájst' výlučne dôkazy o Körperovej zrade, on sám vo svojich textoch nachádzal iba protidôkazy. V tomto zmysle sa odvoláva na svoje úvodníky ešte v spomienkach, vyzývajúc budúcich historikov, aby na ich základe zhodnotili jeho vinu či skôr nevinu. ${ }^{15}$

V štúdii sa venujem najskôr tým textom, v ktorých sa Karol Körper zaoberal Židmi. Ak však chceme pochopit' dynamiku Körperovho politického radikalizmu, musíme jeho antisemitizmus uviest' do súvislosti s tematicky príbuznými okruhmi, ako rozvíjajúci sa kult vodcu, vztah k fašizmu a nacizmu či fenomén politického mučeníctva. Tieto tendencie ovládli Körperovu publicistiku v čase trvania autonómnej Slovenskej krajiny od októbra 1938 do marca 1939 a naplno prepukli v prvých mesiacoch Slovenského štátu. Druhým t’ažiskom mojej analýzy preto budú Körperove články uverejnené v období autonómie a krátko po vyhlásení Slovenského štátu.

Kým do začiatku spolupráce so Slovenskou pravdou nemáme o Körperovom antisemitizme prakticky žiadne doklady, od tohto momentu akoby sa s jeho útokmi proti „židobol’ševikom“ roztrhlo vrece. V apríli 1936, ked’ Sidor interpeloval vládu pre cenzúru svojho antisemitského článku, Körper napísal jeden zo svojich prvých úvodníkov pre Slovenskú pravdu, v ktorom dokazoval, že všetci vplyvní l'udia v Sovietskom zväze boli Židia - s výnimkou Stalina, ale ten vraj mal Židovku aspoň za ženu. Prostredníctvom citátov z antisemitskej literatúry Körper svojim čitatel'om sugeroval, že v Sovietskom zväze sa schyl'uje k akejsi druhej revolúcii, nasledujúcej po bol'ševickej: „Ked’ sa ruský nacionálny duch čo len trochu preberie z mrákot, príde druhá etapa: vyvlastnenie Židov. Len vtedy nastane diktatúra proletariátu namiesto terajšej diktatúry nad proletariátom."16 Okrem Ruska, kde je protižidovské povstanie len otázkou času, píše Körper v predvečer bratislavských demonštrácií proti filmu Golem, to vraj hrozí aj všade inde: „V ostatnej Európe však aj ten najmenší komunistický pohyb bude končit' vyháňaním Židov... "17 V podobnom duchu sa nieslo množstvo d’alších úvodníkov pod značkou Dr. k. k. ${ }^{18}$ Körperova posadnutost' „židobol’ševizmom“ nadobudla také rozmery, že proti nemu pravidelne polemizovali aj komunistické Slovenské zvesti, ktorých redaktori a spolupracovníci, mimochodom, tiež neodolali pokušeniu vlastnej verzie antisemitizmu, ked' Körpera a d’alších l'udákov odhal'ovali ako údajných „židovských zapredancov“ ${ }^{19}$

Karol Körper však Židov neobviňoval iba zo šírenia bol'ševizmu či slobodomurárstva, ale $\mathrm{v}$ duchu svojho konšpiračného myslenia taktiež z ekonomického

15 KÖRPER-ZRÍNSKY 1993, s. 137.

16 Dr. k. k. Židia. In Slovenská pravda, roč. 1, č. 43, 21. apríla 1936, s. 1.

17 Dr. k. k. Palestína. In Slovenská pravda, roč. 1, č. 46, 24. apríla 1936, s. 1.

18 SZABÓ, Miloslav. Klérofašisti. Slovenskí kňazi a pokušenie radikálnej politiky (1935 - 1945). Bratislava : Slovart, 2019, s. 42.

19 Pozri napr. Kto dal maces Körperovi? In Slovenské zvesti, roč. 2, č. 67, 7. apríla 1937, s. 3; Hlinkovci sa spojili so židmi. In Slovenské zvesti, 1937, roč. 2, č. 100, 28. mája 1937, s. 1. 
vykorist'ovania. Körperove protižidovské útoky boli výrazom moderného katolíckeho antisemitizmu, ktorý sa v Európe rozvíjal najneskôr od konca 19. storočia. ${ }^{20}$ Na rozdiel od staršieho antijudaizmu moderní Židia už neboli obviňovaní iba z neuznania, či dokonca z násilnej smrti Ježiša Krista, hoci tieto obvinenia nikdy celkom nevymizli. Podobne ako sekulárni antisemiti pokladala aj čast' katolíckych duchovných a laikov Židov za stelesnenie negatívnych tendencií modernizačných procesov. Popri sociálnoekonomických dôsledkoch kapitalistickej transformácie však katolícki antisemiti stotožňovali židovskú emancipáciu s politickým liberalizmom, ktorý bol vnímaný ako hlavný protivník vytláčajúci cirkev z pozícií v rodinnej politike, kultúre a školstve. Židia sa preto stali súčastou protiosvieteneckých, konšpiračných fantázií o sprisahaní slobodomurárov, liberálov, socialistov, komunistov proti cirkvi a krestananskému štátu. ${ }^{21}$ Vzhladom na príbuznost' katolíckeho so sekulárnym antisemitizmom sa preto aj mnohí klerici začali odkláňat’ od tradičného antijudaizmu. Ten síce Židov démonizoval, ale ked’že Vatikán pokladal obrátenie Židov za podmienku spásy, svojím spôsobom ich „ochraňoval“.22 V dôsledku tohto zblíženia medzi sekulárnymi a krest’anskými antisemitmi sa začali aj v katolíckom prostredí šírit’ fantázie o „židovskej rase“, ktorej údajne nemenitel'né vlastnosti u mnohých spochybňovali dokonca aj sviatost' krstu. ${ }^{23}$

Ani Karol Körper preto nehlásal iba jeden „druh“ antisemitizmu, ale popri „židobol'ševizme" pestoval celý rad d’alších stereotypov vrcholiacich v predstave celosvetového sprisahania Židov či „židovskej rasy“ proti krest’anstvu a štátu, presnejšie proti katolíckej cirkvi a slovenskému národu. Tento konšpiračný antisemitizmus bral na seba rozličné podoby. Napríklad Körperom navrhované „riešenie židovskej otázky“ spočiatku charakterizoval takzvaný hospodársky antisemitizmus: spoločenský a hospodársky bojkot Židov. Podobne ako iní, predovšetkým katolícki antisemiti, ani Karol Körper otvorene nepropagoval protižidovské násilie. V apríli 1937 síce nadšene privítal návrh Karola Sidora vystahovat' Židov zo Slovenska do Birobidžanu, no ako "totálne riešenie“ ho "nateraz ešte" odmietol, „pretože hospodársky život by u nás celkom ochrnul bez židov“. ${ }^{24}$ Körper namiesto toho presadzoval postupné vytláčanie Židov z pozícií v hospodárstve a slobodných povolaniach. No hned' v d’alšom článku Körper projekt Birobidžan prezentoval ako doklad celosvetového židovského sprisahania, ktorého nástrojom je vraj kapitalizmus i komunizmus súčasne. Podpora sovietskych plánov

20 BLASCHKE, Olaf - MATTIOLI, Aram (eds.) Katholischer Antisemitismus im 19. Jahrhundert. Ursachen und Traditionen im internationalen Vergleich. Zürich : Füssli, 2000; FRANKL, Michal. "Can We, the Czech Catholics, be Antisemites?" Antisemitism at the Dawn of the Czech Christian-Social Movement. In Judaica Bohemiae, 1997, roč. 33, s. 47-71; SZABÓ, Miloslav. Náboženské alebo rasové sprisahanie? Antisemitizmus v publicistike katolíckeho kňaza Andreja Rojka. In ROGUL'OVÁ, Jaroslava - JAKSICSOVÁ, Vlasta (eds.) Historik a dejiny. Jubileum Ivana Kamenca. Bratislava : Veda, 2018, s. 35-48.

21 ROGALLA VON BIEBERSTEIN, Johannes. Die These von der Verschwörung 1776 - 1945. Philosophen, Freimaurer, Juden, Liberale und Sozialisten als Verschwörer gegen die Sozialordnung. Frankfurt am Main : Lang, 1976.

22 BRECHENMACHER, Thomas. Der Vatikan und die Juden. Geschichte einer unheiligen Beziehung vom 16. Jahrhundert bis zur Gegenwart. München : C. H. Beck, 2005.

23 MICHAEL, Robert. A History of Catholic Antisemitism: The Dark Side of the Church. New York : Palgrave Macmillan, 2008, s. 193-204. Pozri aj CONNELLY, John. From Enemy to Brother: The Revolution in Catholic Teaching on Jews, 1933 - 1965. Cambridge : Harvard University Press, 2012.

24 Dr. k. k. Birobidžan. In Slovenská pravda, roč. 2, č. 81, 9. apríla 1937, s. 1. 
na židovskú autonómnu oblast’ Birobidžan v časti západnej tlače sa tým v Körperových očiach mení na dôkaz „rasovej spolupatričnosti židov celého sveta“. ${ }^{25}$

Karol Körper sa síce navonok dištancoval od rasistického antisemitizmu nacistov, no napriek tomu s obl’ubou používal vo vzt’ahu k Židom biologické prirovnania, napríklad že „sa vedeli zariadit’ ako cudzopasníci v iných štátoch medzi národmi“.26 Podobne ako mnohí iní politicky radikalizovaní katolíci tej doby aj Körper vo svojej averzii proti Židom preberal rasistický slovník a aktualizoval ním náboženské a iné predsudky. Napríklad v článku o konflikte na Blízkom východe z roku 1937 zhrnul postoj krest’anov k židovstvu tradičným náboženským spôsobom. Hned' na to však náboženskú nevraživost' podčiarkol inou terminológiou. Za odmietanie krest’anskej pravdy podla Körpera vraj netrpeli iba Židia, ale nepriamo aj krest’ania, „ktorí pre nevraživost' a nejednotnost' sa stávajú všade obet'ami tejto cudzej ra$s y “{ }^{27}$ Židovský štát je preto aj v záujme Nežidov - jednak sa tým zbavia „balastu“, ktorý nevykážu, ale spravodlivo pošlú „domov“ a jednak urýchlia vlastnú spásu, ktorej podmienkou je obrátenie Židov na konci vekov.

Z uvedeného je zrejmé, že židovská otázka, ktorú interpretoval v duchu konšpiračného antisemitizmu ako celosvetové sprisahanie Židov proti krest’anským národom, Karola Körpera už pred vyhlásením autonómie Slovenskej krajiny zamestnávala takmer denno-denne. Horúčkovite hl'adal jej riešenia - od bojkotu Židov cez návrhy na obmedzenie ich počtu a dôležitosti v sociálnoekonomickej oblasti až po úvahy o ich vysídlení či vyst’ahovaní, pričom neustále kolísal medzi náboženským a nacionalistickým, ba dokonca rasistickým zdôvodňovaním potreby týchto opatrení. Rasizmus paradoxne netematizoval v kontexte protikrestanského nacistického Nemecka, ktoré v súlade s encyklikou pápeža Pia XI. Mit brennender Sorge (S pálčivou starost’ou) kritizoval, ale demokratickej Ameriky. Príležitost' sa mu naskytla na jeseň 1937, ked' Körper spolu s Jozefom Tisom a d’alšími delegátmi najväčšej slovenskej katolíckej organizácie Spolok svätého Vojtecha absolvoval turné po Spojených štátoch amerických, kde sa usilovali o oživenie stykov so slovenskými emigrantmi alebo s ich potomkami. Zážitky Körper zaznamenal v úvodníkoch, ktoré s oneskorením vychádzali v Slovenskej pravde a hned' po návrate v cestopise Z Bratislavy do Chicaga, ktorý však knižne vyšiel až v roku $1941 .^{28}$

Karol Körper pôvodne vnímal židovskú otázku ako náboženský a sociálnoekonomický problém. Nemecký rasizmus prejavujúci sa vzývaním vznešenej nordickej rasy a zároveň ako extrémny, kvázi mystický antisemitizmus v duchu spolitizovanej predstavy o vyvolenom národe bol preto preňho tak trochu záhadou. Rasovú segregáciu zažil až v USA - spolu s komentármi amerických Slovákov, ktorí sa s touto odvrátenou stranou americkej demokracie do vel'kej miery identifikovali. ${ }^{29}$ Aj Körper vo svojom cestopise prevzal perspektívu radikálnej americkej pravice,

25 Dr. k. k. Do Birobidžanu. In Slovenská pravda, roč. 20, č. 109, 14. mája 1937, s. 1.

26 Dr. k. k. Vlast’ naša. In Slovenská pravda, roč. 2, č. 150, 4. júla 1937, s. 1.

27 Dr. k. k. Izrael. In Slovenská pravda, roč. 2, č. 207, 11. septembra 1937, s. 1.

28 KÖRPER, Karol. Z Bratislavy do Chicaga. Trnava : Spolok sv. Vojtecha, 1941.

29 ZECKER, Robert M. Race and America's Immigrant Press: How the Slovaks Were Taught to Think like White People. New York : Continuum, 2011. 
ktorá hlásala nadradenost' „bielej rasy“ (white supremacy) a zároveň sa obávala jej úpadku v dôsledku rasového miešania: „Čierny problém je jedným z najtrápnejších [najbolestivejších, M. S.] problémov Únie. Biela rasa umiera, čierna sa množí ohromne rýchlym tempom. A kde sa táto rasa zahniezdi, tam viac tráva nerastie. Okupujú celé štvrte. Kam sa dostane černošská rodina čo len do blízkosti, odtial' sa bieli vyst'ahujú. Ked' to takto pôjde, Američania sa obávajú, že budú mat' čoskoro čierneho prezidenta. ${ }^{\text {‘30 }}$

Miešanie rás bratislavský kanonik Karol Körper pokladal za tragédiu demokratickej Ameriky, v neposlednom rade kvôli amerikanizácii státisícov slovenských vystáahovalcov: „(G)enerácie americké sa pomaly stratia $v$ mori národov, z ktorých sa tvorí akási nová rasa: Američan. A tých Američanov bude vždy viac a Slovákov vždy menej. [...] Dobre sa majú, slobodne žijú, ale táto dobrota a sloboda ich zabíja. Pomaly, ale isto. ${ }^{31}$ Katolícky kňaz Körper dospel v USA k presvedčeniu, že Slováci si zachovali svoju „rasovú čistotu“ dokonca aj vtedy, ked” už neovládali poriadne rodný jazyk, čo by malo oficiálne byt' hlavným kritériom ich etnickej príslušnosti. Toto poznanie sa $\mathrm{v}$ ňom prebudilo pri pohlade na katolíckych školákov v pennsylvánskom mestečku Allentown: „Niektoré ani to nevie, čo znamená »otec«, alebo "matka", ved" ich rodičia sami už nehovoria po slovensky. A predsa sú to slovenské deti. Čisto slovenské. Bez miešaniny. Povedzme: rasove slovenské. Krásne, belasé [blond, M. S.] hlavičky, nevinné, múdre oči, všetko čisto vyobliekané. ${ }^{132}$

V USA si Karol Körper pochopitel'ne všímal aj Židov. Zaujali ho najmä chudobní imigranti vo Filadelfii pripomínajúci černochov. Paralely medzi oboma rasami, ako ich nazýval, videl v tom, že obe sú na najnižších priečkach spoločenského rebríčka, na vrchu ktorého tróni anglosaská rasa pôvodných pristahovolcov. Práve preto sú semeništami komunizmu. Na základe týchto pozorovaní Körper zovšeobecňuje svoju teóriu židobol'ševizmu: „Tu, v Amerike, vidiet', že celý komunizmus nie je nič iného, ako pomstou nenávidenej rasy. ${ }^{\text {(33 }}$ Körper čitatela síce následne uist'uje, že za pomstu utláčaných rás môžu aj nespravodlivé spoločenské pomery, vo svojom resumé americkej skúsenosti však otvorene priznáva, že rovnako ako iní konšpirační antisemiti aj on pokladal židovskú rasu za zásadne odlišnú od iných rás, ked’že jej podstatou sú údajne materializmus a túžba po svetovláde - za týmto účelom vraj Židia šíria spoločenský, národný a náboženský rozklad v podobe liberalizmu a komunizmu.

Skôr než sa Žid vypracuje na kapitalistu, je podla Körpera komunistom, ba ešte aj potom hrá „dvojakú úlohu“, dodáva v konšpiračnom duchu. Zatial’ čo amerikanizácia zbavuje pristahovalcov ich národnosti výmenou za inú, pričom u národov ako Slováci, u ktorých je vraj národnost' pevne zviazaná s vierovyznaním, to môže implikovat' aj stratu viery, židovský kapitalizmus a komunizmus sú o niečom celkom inom. Židovská rasa podla Körpera stelesňuje pud, vôlu po moci,

\footnotetext{
30 KÖRPER 1941, s. 127.

31 Tamže, s. 152.

32 Tamže, s. 283.

33 Tamže, s. 244.
} 
snahu opanovat' svet pomocou prázdnych hesiel o slobode a sebarealizovaní, ktoré majú zakryt' podstatu problému, ktorým je údajne vrodené úsilie Židov a ich potreba a schopnost' žit' na úkor druhých, udržiavat' ich v nevedomosti pomocou vidín a fatamorgán. ${ }^{34}$

Na prelome rokov 1937 a 1938 sa v strednej Európe začalo schylovat’ k prevratným zmenám. Po Taliansku sa do protikomunistického frontu hlásilo Mad’arsko, v Rumunsku sa k moci dostal režim presadzujúci antisemitskú politiku. Začiatkom januára 1938 Karol Körper v Slovenskej pravde predpovedal zahraničnopolitickú izoláciu Československa, pretože sa ako jediné v regióne neprofilovalo protikomunisticky a nekritizovalo Spoločnost' národov pre údajný vplyv slobodomurárskych lóží. Predovšetkým však zostávalo hluché k antisemitizmu, na rozdiel od fašistickej internacionály, ktorá si vraj vel'mi dobre uvedomovala nebezpečenstvo hroziace od medzinárodného židovstva, teda od židovských kapitalistov a komunistov.

Karol Körper sa však nechcel nečinne prizerat'. Jednou z jeho aktivít bola činnost' v Slovenskej lige, pôvodne nadkonfesionálnej a neautonomistickej inštitúcii, ktorá mala posilňovat' slovenské etnikum predovšetkým v zmiešaných jazykových oblastiach na južnom Slovensku. Okrem toho spolupracovala s takzvaným slovensko-židovským hnutím, ktoré žiadalo od Židov, aby sa hlásili za Slovákov a pestovali slovenskú kultúru. ${ }^{35}$ Demonštrácie proti filmu Golem v apríli 1936 zmenili aj tento ústretový prístup, a síce zásluhou Karola Körpera. Slovenská liga zorganizovala krátko na to diskusiu o židovskej otázke, kde spolu s Körperom vystúpil radikálny l'udák Ferdinand Ďurčanský, neskôr minister slovenskej vlády a autor právnej definície, ktorá sa stala súčastou prvého protižidovského zákona bezprostredne po vyhlásení Slovenského štátu. Körper sa už v roku 1936 vyslovil proti poslovenčovaniu židovského obyvatel'stva, „lebo my kultúru pokladáme za prejav národnej duše ". ${ }^{36}$ Okrem toho otvorene požadoval zavedenie takzvaného numeru clausu v hospodárskej oblasti, to znamená, že Židia by mali v ekonomike zastúpenie neprekračujúce ich percentuálny podiel na obyvatel'stve. Ten istý princíp mal platit' u príslušníkov takzvaných slobodných povolaní ako lekári a právnici.

V máji 1938 mad’arské úrady takýto numerus clausus čiastočne implementovali. Karol Körper to pokladal za vhodný moment, aby vystúpil pred slovenskú verejnost' so svojím návrhom na „riešenie židovskej otázky“. Urobil to v časopise Slovenská liga a ide o prvý podrobný plán predznamenávajúci spomínaný protižidovský zákon z dielne Ďurčanského. Tento plán, ktorý Körper cynicky nazval „slovensko-židovská pätiletka“,37 obmedzoval pobyt Židov na Slovensku ako aj ich majetkové práva a výkon povolania. Ako zlomový bod stanovil vznik ČSR v roku

34 Tamže, s. 513-514.

35 LETZ, Róbert. Dejiny Slovenskej ligy na Slovensku (1920 - 1948). Martin : Matica slovenská, 2000, s. 233238.

36 Demokraciu na Židov! In Slovák, roč. 18, č. 240, 20. októbra 1936, s. 4.

37 KÖRPER, Karol. Ako by sa dala riešit' národne a hospodársky židovská otázka? In Slovenská liga, roč. 15, č. 5, máj 1938, s. 115. Körperova agresívna narážka na stereotyp židobol'ševizmu očividne unikla R. Letzovi, ktorý o nej referuje, akoby šlo o neutrálny časový údaj. LETZ 2000, s. 239. 
1918: Židia, ktorí sa pristahovali neskôr, nemali mat' na Slovensku právo pobytu. 0 realizáciu tohto nariadenia sa mal postarat' štát a rovnako mal byt' nápomocný Slovenskej lige pri súpise hnutel’ného i nehnutel'ného majetku, ktorého objem nesmel presahovat' podiel Židov na celkovom obyvatel'stve. Numerus clausus sa mal zaviest' na úradoch, v obchode a v slobodných povolaniach. Najprísnejší bol posledný bod Körperovho programu, ktorý protinárodným a protikrestanským Židom hrozil prenasledovaním: „Každý Žid, ktorý propaguje alebo akýmkolvek spôsobom napomáha akciu smerujúcu proti slovenskej národnej a krestanskej myšlienke, musí byt' trestaný a vypovedaný. ${ }^{\prime 38}$

V daných súvislostiach je rozhodujúce, že v Körperovom pláne nachádzame prvý pokus o definíciu Žida, ktorá - presne ako o necelý rok neskôr u Ďurčanského ${ }^{39}$ miešala konfesionálne charakteristiky s rasovými: „Taktiež, nakol'ko židovská rasa má od slovenského národa a slovanskej rasy celkom odlišnú náturu a náchylnosti, žiaden Žid nemá byt' pripustený do slovenského kultúrneho a politického života (novinárstvo, literatúra, divadlo, film), iba ked' už pred prevratom patril k akejsi krestanskej konfesii a tým dokázal, že sa zrieka špecifických rasových prostriedkov, ktoré tvoria židovskú mentalitu. ${ }^{40}$ Zdá sa, že podla Körpera a Ďurčanského vierovyznanie - na rozdiel od nacistických zákonov, ktoré sa na Slovensku zaviedli až v roku 1941 - akoby dokázalo menit’ rasovú predurčenost', existencia ktorej sa však zároveň prijímala a nespochybňovala, práve naopak, prezentovala sa ako koreň židovskej hrozby. ${ }^{41}$ Podmienkou bolo, aby k zmene konfesie nedochádzalo z oportunistických pohnútok. Celé toto rozlíšenie stálo na hlinených nohách, lebo zahmlievalo rozdiel medzi národnost'ou („rasa“) a konfesiou. Ako sa dalo zistit', že niekto nezmenil vierovyznanie pred rokom 1918, teda ešte za čias Uhorska, zo ziskuchtivosti? A nebolo by to ešte horšie, keďže vtedy to vo všeobecnosti neimplikovalo príklon k slovenskému presvedčeniu, ale mad’arizáciu?

\section{Na vrchole radikalizovania. Obdobie autonómie a prvé roky Slovenského štátu}

V októbri 1938 si Karol Körper spolu s d’alšími l’udákmi vychutnával plody svojho publicistického boja za autonómiu. Jeho čoraz vlažnejší postoj k československej demokracii vystriedalo prakticky zo dňa na deň oslavovanie autoritárskych vodcov a fašistického heroizmu. Na nasledujúcich stranách sa pozrieme na Körperovu politickú radikalizáciu všeobecnejšie, lebo bez zohladnenia týchto tendencií sotva pochopíme jeho nadšené volanie po „riešení židovskej otázky“ v rokoch 1939 a 1940.

38 KÖRPER, Karol. Ako by sa dala riešit' národne a hospodársky židovská otázka? In Slovenská liga, roč. 15, č. 5, máj 1938, s. 115.

39 NIŽŇANSKÝ, Eduard (ed.) Holokaust na Slovensku: Obdobie autonómie (6. 10. 1938 - 14. 3. 1939). Dokumenty. Bratislava : Nadácia Milan Šimečku, 2001, s. 130-134.

40 KÖRPER, Karol. Ako by sa dala riešit' národne a hospodársky židovská otázka? In Slovenská liga, roč. 15, č. 5, máj 1938, s. 115.

41 Vzhl'adom na Körperov agresívny tón sa sotva dá súhlasit’ s kategorickými (či skôr apologetickými) súdmi R. Letza: „Termín rasa sa [v Körperovom texte, M. S.] nepoužíva v nacistickom zmysle nadriadenej [?] a podriadenej rasy. Ide o vyjadrenie odlišnosti. Skôr sa tým priznáva slovenská slabost', nepodnikavost' a nepružnost'v kultúrnom a politickom živote." LETZ 2000, s. 239. 
Karol Körper mal slabost' pre autoritársku politiku už v 20. rokoch, ked' podobne ako iní rodobranci vítal taliansky fašizmus a jeho vodcu Benita Mussoliniho. Ničím nehatený obdiv k osobe vodcu prepukol u Karola Körpera po vyhlásení autonómie Slovenska v októbri 1938. Körper, ktorému sa dostalo cti privítat’ novú slovenskú vládu v Bratislave, prifarbil svoju úctu k novému vodcovi, vtedy ešte len predsedovi autonómnej slovenskej vlády Jozefovi Tisovi náboženskými metaforami znovuzrodenia. V prejave, ktorý vyšiel ako úvodník Slovenskej pravdy, zároveň účtoval so svetonázorovými nepriatel'mi, slobodomurármi a Čechmi: „Dnes slávime svoje Vzkriesenie! Pán predseda slovenskej vlády, vy ste tým božím anjelom, ktorého nám Boh poslal, aby odvalil t’ažký kameň sponad hrobu nášho národa. Už Slovensko vstáva, putá si strháva! Vítazne tiahne prvý ministerský predseda slovenský do hlavného mesta Slovenska, do toho staroslovenského usadliska, do Bratislavy, i so svojimi ministrami. Mocne siaha po kormidle slovenského národa. Mocne, rukami čistými, rukami vol’nými. Tieto ruky sú nielen ruky Slováka a vlastenca, ale aj ruky katolíckeho kňaza, ruky pomazané, ruky vysvätené, akými boli žehnajúce ruky Andreja Hlinku, najväčšieho kňaza slovenského. Že kňaz kráča na čele prvej slovenskej vlády, to znamená predovšetkým radost' a vít’azstvo katolíckeho kňazstva a katolíckych veriacich na Slovensku. Znamená to vít’azstvo pravdy, vít'azstvo naše nad slobodomurárskou temnotou a nad hnilobou marxizmu, znamená to vít'azstvo krest'anstva nad tými, $v$ srdciach ktorých nehorela láska $k$ nášmu l'udu, ale šl'ahali bezočivé plamene krematórií." ${ }^{42}$ Nenávidený centralistický režim, stotožňovaný s marxizmom a nekatolíckymi obradmi (proti zámerom postavit' v Bratislave krematórium sa v Slovenskej pravde viedli polemiky ešte pred vyhlásením autonómie, ked'že katolicizmus kremáciu zakazoval), Körper prirovnával k nesvedomitému záhradníkovi, ktorý namiesto zvel'ad’ovania sadil „cudzie zeliny, pichliače a žihl'avu“, kým „slovenský kvet drsnou rukou vytrhol zo zeme a hodil do smetí" ${ }^{43}$ Po vzniku Slovenského štátu 14. marca 1939 si preto s úlavou vydýchol, že Československo, údajne iba „platený predvoj“ Západu, ktorému vraj „nikdy nešlo o naše národné snahy, ale len o sebecké záujmy","4 zaniklo.

Karol Körper mal na nacizmus vyhranený názor najneskôr v roku 1937. Podobne ako mnohí konzervatívni klerici bol najskôr rozpoltený - na jednej strane vítal antikomunizmus a aj antisemitizmus ako zásadnú zložku národno-socialistického svetonázoru, no na druhej strane odmietal „nové náboženstvo rasy a krvi“ ako „hnedý bol'ševizmus“: „Nacionálny socializmus ako hromadný a národný pohyb vedel sa postavit' na odpor proti najväčšiemu nepriatelovi dnešného l'udského pokolenia, proti komunizmu, ba vedel zdolat' aj tú najväčšiu moc hospodárskeho sveta, medzinárodné židovstvo. Avšak v riadnom živote, ako svetový názor, sa ukazuje byt' nie lepším, ako bol'ševizmus. [...] Komunizmus odstraňuje kríže a spal'uje. Hnedé pohanstvo zachová kríž, ale ho zlomí. A to je ešte horšie!"45 Körper však zároveň dal

42 Dr. k. k. Víta vás. In Slovenská pravda, roč. 3, č. 158, 12. októbra 1938, s. 2.

43 Dr. k. k. Prebudovat'. In Slovenská pravda, roč. 3, č. 161, 15. októbra 1938, s. 1.

44 Dr. k. k. Koniec. In Slovenská pravda, roč. 4, č. 64, 18. marca 1939, s. 1.

45 Dr. k. k. Protijed. In Slovenská pravda, roč. 2, č. 52, 5. marca 1937, s. 3. 
najavo, že k nacizmu má podla neho katolicizmus predsa len bližšie práve preto, že ich spája spoločný nepriatel' - židobol'ševizmus. Vydanie encykliky $S$ pálčivou starostou v marci 1937 komentoval nasledujúcim spôsobom: „Katolicizmus nepodlieha ani židovskému komandu moskovskému, ani bombastickým rozkazom generálov hitlerovských. Pápež má pred sebou l'udí celého sveta a háji ich slobodu proti každému násilníkovi, či je to kapitalista alebo proletár, či žid alebo rasista. Katolicizmu sa protiví každé otroctvo."46

V roku 1937 Karol Körper pokladal Československú republiku napriek všetkej kritike za slobodnejšiu a morálne nadradenú nacistickému Nemecku, kde jednotlivec musí „podrobit' svoju vôlu jednej centrálnej vôli, a musí prijat' krédo nemecko-nacionálno-socialistické “. ${ }^{47}$ Svoju náklonnost' k Hitlerovi však neobjavil až po vyhlásení Slovenského štátu v marci 1939. V článku Hitler, ktorý napísal pri príležitosti anšlusu Rakúska v marci 1938, Körper konštatoval, že „jeho národná idea zdolala slabšiu národnú ideu Schuschnigovskú".48 Nešlo o suché konštatovanie, ked'že svoju zaujatost' musel priznat' ešte aj v obhajobe pred Národným súdom, kde sa inak štylizoval do pozície záchrancu Židov: „Poukázal som na isté momenty, ktoré prispely $k$ úspechu Hitlerovmu, medzi nimi na odpor viedenského obyvatelstva proti mnohým Židom. Túto čiastku článku naša cenzúra nepovolila."49

V čase autonómie už Karol Körper otvorene privítal príklon Nemcov na Slovensku k nacizmu, ked’že ten bol teraz podla neho zdravým princípom spočívajúcim na jednote medzi ludom a vodcom. Körper vtedy už nebral vážne výstrahy, že „po židoch príde na rad cirkev a kňazi“, či dokonca slovenský národ ako taký, lebo Slováci vraj boli vernými žiakmi svojich nemeckých a talianskych učitel'ov: „A toto Nemci rešpektujú, lebo žiaden majster nezabíja svojho žiaka vtedy, ked' vidí, že je dostatočne vyučený a pre život ozbrojený. "50 Ani kňazi sa nemajú čoho obávat', ked'že boli na Slovensku vodcami národnej revolúcie. V decembri 1938, teda ešte v čase existencie Česko-Slovenskej republiky, si preto Körper dovolil napísat’ v úvodníku rozšíreného denníka vetu, za ktorú by ho ešte pred niekol'kými mesiacmi mohli obvinit' z vlastizrady, nehovoriac o tom, že by ju okamžite vybielila cenzúra: „U nás, na našom slobodnom Slovensku, je hákový kríž práve tak znakom národnej obrody a nového života, ako slovenský dvojkríz:. “51 Vzhladom na túto ústretovost' neprekvapuje, že Körper privítal, takisto ešte pred vznikom Slovenského štátu, založenie Slovensko-nemeckej spoločnosti v Bratislave ako nápravu „židofilským režimom“ ČSR pošramotenej povesti Nemecka: „Bratislava, hlavné mesto Slovenska bude styčným terénom nemeckej a slovenskej kultúry, najúprimnejších pokusov spolupráce Germánstva a Slovanstva. My, Slováci, svojou centrálnou polohou, neutralitou

46 Dr. k. k. Tri encykliky. In Slovenská pravda, roč. 2, č. 77, 4. apríla 1937, s. 1.

47 Dr. k. k. Na Hitlera. In Slovenská pravda, roč. 2, č. 204, 8. septembra 1937, s. 1.

48 Slovenský národný archív (SNA), fond (f.) Národný súd (NS), Tnlud 17/45, Osvedčenie Karola Körpera o svojej úvodnikarskej činnosti pri denníku „Slovenská pravda“ v rokoch 1936 - 39, ako doplňok k výsluchu prevedenému dňa 12. VII. 1945.

49 Tamže.

50 Dr. k. k. Naši Nemci. In Slovenská pravda, roč. 3, č. 221, 30. decembra 1938, s. 1.

51 Tamže. 
a nekompromitovanou politikou národnou reprezentujeme tu celé Slovanstvo, ktoré podáva mocným Germánom bratskú a pomocnú ruku. Národní Germáni a národní Slovania majú svojich spoločných nepriatelov a svoje spoločné hospodárske a sociálne starosti. My, Slováci, radi budeme tu mostom a sprostredkovatel'mi. ${ }^{.52}$

Rastúce nadšenie pre nacizmus v čase autonómie môže vysvetl’ovat' aj fakt, že Karol Körper sa dokonca nepriamo prihlásil k eugenike, ktorú pápež Pius XI. odsúdil v encyklike Casti connubii z roku 1930. Körper krátko pred vznikom Slovenského štátu v jednom z úvodníkov Slovenskej pravdy uvažoval o zdraví národa nasledujúcim spôsobom: „Slovák, ako typ človeka, je krásavec [...] vysoký, štíhly, svalnatý. Slovenka je na celom svete známa svojím príjemným a zdravým zjavom. My sa musíme usilovat', aby slovenský národ držal sa týchto svojich typov a aby vôbec nemal nepodarencov. ${ }^{153}$ Inými slovami, katolícky kňaz Körper sa prejavil ako zástanca eugeniky alebo - v dnešnom jazyku - génového inžinierstva, ktoré pomocou umelých koncepcií malo posilňovat' vhodné dedičné vlohy, respektíve eliminovat' škodlivé dedičné choroby celých populácí či rás, predovšetkým formou sterilizácie. Spôsob, akým požadoval udržiavat' zdravie národa, neprezrádzal krestáanský súcit s chorými, skôr naopak. Úlohu dohl'adu na zdravie národa mal prevziat' štátny zdravotný ústav, ktorý „,bude musiet’ odstránit' všetkých zo spoločnosti, ktorí vplývajú škodlivo na vzrast a dobrý telesný vkus obecenstva. Mrzákov, kreténov, nevyliečitelných treba dat' do špeciálnych ústavov, aby neboli na t'archu obecenstva a neboli vystavení posmechu l'udí. ‘54

Karol Körper však nezostal iba pri publicistike. Fašizácii Slovenska napomáhal už počas autonómie aj politicky, predovšetkým z titulu svojej funkcie duchovného správcu Hlinkovej gardy. Fašizmus sa často stotožňuje so zdanlivo samoúčelným aktivizmom, ktorý sa nielenže nevyhýba teroru a násiliu, naopak, ospevuje ich a praktikuje v boji proti nepriatel'om na čele so socialistami a inými údajnými predstavitel'mi spoločenského rozkladu ${ }^{55} \mathrm{~K}$ vonkajším znakom fašizmu patria polovojenská organizácia, uniformované pochody či kult hrdinstva a dobrovol'nej obete - mučeníctvo, ale aj pestovanie kultu mužnosti. ${ }^{56}$ Tieto znaky spájali talianskych squadristov s nemeckou Sturmabteilung (SA), ale aj so slovenskou Rodobranou v 20. rokoch 20. storočia. 010 rokov neskôr štafetu prevzala Hlinkova garda. Karol Körper sa aktívne zapojil do jej budovania.

Fašistickí mučeníci neboli iba symbolom neochvejnej viery, ale mali užšie (strana, polovojenské jednotky) a širšie národné spoločenstvo zaväzovat' a nabádat' k d’alšej politickej či vojenskej aktivite. V medzivojnovom období apelovali na politické mučeníctvo v mene národa aj mnohí prominentní predstavitelia katolíckej cirkvi. Tieto snahy registrovali taktiež reprezentanti a orgány HSL'S. Mučeníctvo sa v ich očiach stávalo nástrojom náboženskej i politickej, konkrétne národnej obrody. ${ }^{57}$ Ako v prípa-

52 Dr. k. k. S Nemcami. In Slovenská pravda, roč. 4, č. 28, 2. februára 1939, s. 1.

53 Dr. k. k. Zdravie. In Slovenská pravda, roč. 4, č. 55, 7. marca 1939, s. 1.

54 Tamže.

55 REICHARD, Sven. Violence and Community: A Micro-Study on Nazi Storm Troopers. In Central European History, 2013, roč. 46, č. 2, s. $275-297$.

56 PAYNE, Stanley. A History of Fascism, 1914 - 1945. Madison : University of Wisconsin Press, 1995 , s. 7.

57 Mýtus znovuzrodenia („Palingenesis“) ako základný prvok fašistickej mytológie zdôrazňuje R. Griffin. GRIFFIN, 
de antisemitizmu, aj tu zohrala španielska občianska vojna rolu akéhosi katalyzátora $\mathrm{v}$ procese miešania náboženstva s radikálnou politikou. Karol Körper komentoval tieto tendencie v úvodníkoch Slovenskej pravdy a vyvodzoval z nich pre neho typické závery. Katolícky klérus i laici na čele so študentmi a básnikmi katolíckej moderny vraj predstavujú akúsi avantgardu idealizmu, odriekania a horúčkovitej aktivity: „Katolícka cirkev nie je cirkvou buržoázie, nie je cirkvou pohodlia, ale cirkvou pracujúcou a bojujúcou. [...] Naši nepriatelia hovoria, že cirkev sa už vyžila, že už nepatrí do modernej doby. Taká spoločnost', ktorej členovia vedia vycedit' svoju krv za nimi hlásanú pravdu, sa nikdy nevyžije, tá zostáva vždy svieža a moderná. Lebo martýrstvo znamená idealizmus, ktorý obrodzuje!'58 Obet' a následná obroda teda nie sú nijaký návrat spät', ale moderný heroizmus, prekonávanie odporu nepriatela, za čo čaká hrdinu sladká odmena, vedomie účasti na večnej spáse. Körper podfarboval inštitúciu vodcu nábožensky, konkrétne nepatričnými odkazmi na askézu (Mussolini) a kult Krista Krála (Hlinka a Tiso) ${ }^{59}$ Podobne to bolo aj v prípade heroizmu. V citovanom úvodníku opisuje mučenícku smrt' istého španielskeho klerika, ktorý na výzvu vojakov, aby vzdal hold komunizmu, lebo inak ho zastrelia, nebojácne zvolal: „»Nech žije Kristus-král!'« Na perách s týmto vyznaním viery padol potom hrdina-kňaz do svojej vlastnej krvi." ${ }^{\text {"60 }}$

Takéto mužné hrdinstvo bolo predovšetkým plodom askézy, odriekania alebo pôstu, ktorého zmyslom je „cvičit' telo a vôlu, aby telo bolo odolnejšie a nie slabým nástrojom mäkkýša, a aby vôla bola zocelená k vel'kej odhodlanosti. Môžu príst' časy, ked'sa budeme musiet' pôstit' aj mimo pôstu, aj bez toho, že by sme sa chceli pôstit'."'11 Tie časy mali príst' už zanedlho a uvedomovali si to aj predstavitelia režimu, ktorí začali pestovat' kult padlých mučeníkov hned' po vyhlásení Slovenského štátu. Ich obet’ bola podla Körpera „krvavou pečiatkou, ale tým cennejšou na dokumente slovenskej slobody“62 Kult mučeníkov si začala vytvárat' aj Hlinkova garda, verne nasledujúc svoje talianske a nemecké vzory, ktoré okolo svojich martýrov spriadali celé rituály. (Podla velitel'a Hlinkovej gardy Alexandra Macha „krv martýrov, krv hrdinov je najväčšia moc sveta!"“3) Táto elita hrdinov ochotných kedykol'vek položit' svoj život na oltár vlasti však mala aj inú úlohu, a síce eliminovat' nepriatelov.

Už Körperove vyhrážky predstavitel'om politickej, hospodárskej a kultúrnej elity v medzivojnovej Bratislave pod heslom boja proti slobodomurárom sa neniesli iba v rovine spoločenského a hospodárskeho bojkotu. V roku 1937 volal po organizácii na obranu pred slobodomurárskymi lóžami, kde sa vraj „bratríčkujú marxisti s buržujmi vesele, zrádzajú naše národné záujmy a prevádzajú svoje pokrokárske plány

\footnotetext{
Roger. The Nature of Fascism. London : Routledge, 1994.

58 Dr. k. k. Mučeníctvo. In Slovenská pravda, roč. 2, č. 49, 2. marca 1937, s. 1.

59 KÖRPER, Karol. Mussolini - muž bez priatel'ov. In Kultúra, roč. 7, č. 1, január 1935, s. 33; Dr. k. k. Brezany. In Slovenská pravda, roč. 4, č. 194, 25. augusta 1939, s. 1; KÖRPER, Karol. Strana v zákone. In Slovák, roč. 24, č. 245, 25. októbra 1942, s. 1.

60 Tamže.

61 Dr. k. k. Pôst. In Slovenská pravda, roč. 4, č. 48, 26. februára 1939, s. 1.

62 Dr. k. k. Hrdinstvo. In Slovenská pravda, roč. 4, č. 112, 14. mája 1939, s. 1.

63 MACH, Šaňo. Zákon krvi. In Gardista, roč. 2, č. 14, 30. marca 1940, s. 1. Mach sa odvolával na gardistického martýra Antona Kopala, zastreleného počas tzv. Homolovho puču v marci 1939.
} 
na poli školstva a verejnosti““64 No zatial’ čo v roku 1937 sa ešte odvolával na príklad amerického katolíckeho spolku Kolumbovi rytieri, v októbri 1938 sa tejto úlohy mala zhostit' novozaložená Hlinkova garda.

Jedným z prvých krokov slovenskej vlády po vyhlásení autonómie bolo rozpustenie slobodomurárskych lóží. Toto opatrenie noví vládcovia v duchu svojich konšpiračných fantázií, ale aj vedome propagandisticky zinscenovali do podoby masovej demonštrácie pred údajnou slobodomurárskou centrálou na Námestí 1. mája v Bratislave. Jej obsadenie sledovalo v nedel'u 16. októbra 1938 niekol'ko tisíc osôb priamo na mieste a ludácka tlač ho štylizovala ako prvý krok na ceste k oslobodeniu spod internacionálneho židovského jarma. Na akte prevzatia budovy predstavitel'mi Hlinkovej gardy na čele s hlavným velitelom Karolom Sidorom sa zúčastnil aj jej budúci duchovný správca Karol Körper. Niekdajšia centrála slobodomurárov bola premenovaná na Dom Andreja Hlinku, v ktorom odvtedy sídlilo hlavné velitel'stvo Hlinkovej gardy. Jej členovia, ktorých Körper pasuje na akýchsi moderných križiakov, obrancov národa a cirkvi, sa mali rázne postavit' proti „freimaurerským kumštom“, ktoré vraj siali rozkol medzi národmi, aby ich podriadili židovskej nadvláde. Bezprostredne po zabratí budovy sa v nej konala prvá prísaha gardistov, ktorí podla Körpera ešte predtým, než začnú budovat' nový poriadok, musia ako správni revolucionári rozbit' ten starý. Jeden zo slobodomurárskych symbolov, kladivko, sa tu mení na zbraň v rukách moderných križiakov, ktorí pod vedením svojho duchovného velitel'a majú stelesňovat' už vo fašistickom zmysle revolučnú obranu pred revolúciou lavicovou: „Na stenách ešte viseli obrazy hlavných predstavitelov svetového a českého slobodomurárstva, aj vel'ký obraz, predstavujúci krvavú revolúciu, symbol to vrcholnej činnosti slobodomurárskej. Ale pod týmito obrazmi v rukách duchovného velitela bol pozdvihnutý do hora svätý kríž, symbol krestáanstva, a pred krížom odhodlaní mladíci slovenskí, ktorí idú do verejnosti očistit' všetko od pliagy a pozostatkov dvadsat'ročného kapitalisticko-bol'ševického režimu. Akoby títo prví Hlinkovi gardisti boli prevzali do svojich pevných a čistých rúk slobodomurárske kladivá, aby vykonali kladivami týmito dvojakú úlohu: rozbit' a rozbúrat' každú protinárodnú baštu a vystavat' krásnu a pevnú budovu národnej budúcnosti.“65

Karol Körper sa spolu s dalšími postavil na čelo tohto predvoja. Do Hlinkovej gardy, ktorá v predstavách l’udáckych autonomistov suplovala neexistujúcu slovenskú armádu, vstupovali už na jeseň 1938 mnohí kňazi. Na podnet predsedu autonómnej vlády Jozefa Tisa bola zriadená Hlavná duchovná správa Hlinkovej gardy - niečo na spôsob vtedajšieho i dnešného vojenského vikariátu, ktorý má na starosti duchovnú starostlivost' v armáde. Cirkevná hierarchia tieto snahy podporovala a zaštitovala. Podla trnavského administrátora biskupa Pavla Jantauscha bolo „mravnou povinnost'ou každého kňaza, aby vládu nového Slovenska aj na tomto poli svojej pôsobnosti statočne a všemožne podporoval ${ }^{\prime \prime}{ }^{66}$ Členom Hlinkovej gardy sa mal údajne stat' aj spišský biskup Ján Vojtaššák, čo sa však nepodarilo dokázat'. Napriek tomu existujú doklady

64 Dr. k. k. Slobodomurári. In Slovenská pravda, roč. 2, č. 31, 9. februára 1937, s. 1.

65 Dr. k. k. Prvá prísaha. In Slovenská pravda, roč. 3, č. 166, 21. októbra 1938, s. 1.

66 Cit. podla KÁRPÁTY, Vojtech. Vae Victis! Poznámky k niektorým životným osudom Dr. Karola Körpera (rukopis). 
o jeho fascinácii touto polovojenskou organizáciou. Vojtaššák vo svojom vianočnom posolstve z roku 1939 celkom v klérofašistickom duchu hladal paralely medzi pomermi na Slovensku a v Taliansku, ktoré kládol gardistom za vzor: „Taliansko bude raz musiet's vel'kou pietou spomínat'si fašistickú dobu Mussoliniho, lebo on disciplínou a prevychovanostou svojich čiernych gárd fašistických nielen zachránil svoj taliansky národ, ale pozdvihol malé a dakedy zosmiešňované Taliansko do radu obávaných vel'mocí, vzbudzujúcich rešpekt." ${ }^{\text {"67 }}$

Hlavnou úlohou duchovnej správy Hlinkovej gardy - mali v nej zastúpenie i evanjelici - mala byt' „mravno-náboženská výchova dôstojníkov, poddôstojníkov i radových gardistov". No nezabúdalo sa ani na brannú výchovu. Na prvom kurze duchovných-gardistov vo Vyhnátovej pri Banskej Bystrici - chatu, ktorú dovtedy používala a asi aj vlastnila československá telocvičná organizácia Sokol, pre istotu hned' po príchode vysvätili - čakalo na zúčastnených bohoslovcov okrem náboženských cvičení ešte čosi iné: „Vodcovstvo vyskúšalo pohotovost' našich kurzistov praktickými cvičeniami a nočnými poplachmi. “68 $\mathrm{V}$ takomto duchu pôsobil v neposlednom rade hlavný duchovný správca Hlinkovej gardy, za ktorého bol vymenovaný Karol Körper.

Toto radikalizovanie sa už v období autonómie prejavovalo príklonom k čoraz drastickejším formám „riešenia židovskej otázky“. Začiatkom roku 1939 Karol Körper v úvodníku Slovenskej pravdy uvažoval o očakávanej etnickej homogenizácii strednej Európy pod záštitou nacistického Nemecka, pričom si ju mylne vysvetloval ako návrat ku „koreňom" jednotlivých etník. Napríklad v Mad’arsku sa z pomad’arčených nemad’arských národností mali stat' opät’ Nemci, Slováci a Židia. No zatial' čo Nežidia mali byt' pod ochranou svojich domovských krajín, pre Židov nebolo miesto nikde. Mad’ari sa ich mali zbavit', podobne ako Poliaci a samozrejme Nemci. Tí však nevedeli, kam ich vyst’ahovat'. Nielen z dnešného pohladu vyznievajú vtedajšie Körperove otázky vel'mi zlovestne: „V Polsku majú štyri miliony Židov, hrozné číslo, čo s nimi? [...] V Mad'arsku, $v$ samom hlavnom meste, $v$ Budapešti, majú štvrtinu obyvatel'stva židovskú. Táto štvrtina má v rukách financie, banky, divadlá, umenie a tlač, - čo s ňou? [...] V Nemecku už zákonmi vyriešili židovskú otázku, ale ešte vždy majú na 800.000 Židov. Nemci sa neuspokoja, kým posledný Žid nepôjde z Nemecka, ale ani tam to nateraz neide." ${ }^{169}$

Eufória po vyhlásení Slovenského štátu 14. marca 1939, zdá sa, podobné otázky zatlačila do úzadia. Iba niekol'ko dní po tomto dátume advokátska komora vylúčila zo svojich radov Židov, čo Karol Körper privítal so zdôvodnením, že po židovských krčmároch boli židovskí advokáti druhým článkom ret’aze odnárodňovania, či už za Uhorska v prospech Mad'arov alebo za prvej ČSR v prospech bolševizmu. 0 štyri mesiace neskôr Körper podobným spôsobom obhajoval zavedenie numeru clausu pre židovských lekárov, z ktorých sa vraj grupovali nesvedomití a skorumpovaní vykonávatelia potratov, čím sa hriešne previnili proti krest'anskému náboženstvu a slovenskému národu, pričom Körper aj v tomto prípade obe oblasti previazal: „Iste mnohí

67 Tamže. O revízii analytického pojmu klérofašizmus pozri SZABÓ 2019.

68 KÁRPÁTY, Vojtech. Vae Victis! Poznámky k niektorým životným osudom Dr. Karola Körpera (rukopis).

69 Dr. k. k. Nespokojnost'. In Slovenská pravda, roč. 4, č. 47, 25. februára 1939, s. 1. 
Židia boli dobrými lekármi, ale nik nemohol od nich žiadat', aby mali ohl'ad na dušu, ktorej svetonázor bol im celkom cudzí, alebo aby napomáhali vzrast a zdatnost' národa, ku ktorému nepatrili." ${ }^{\text {"70 }}$

Prvým vrcholom protižidovskej politiky nového režimu už niekol'ko týždňov po vyhlásení štátu bol takzvaný prvý židovský zákon obsahujúci Ďurčanského definíciu Žida, ktorú Körper v máji 1938 predznamenal. Tento právny základ, od ktorého sa mali odvíjat' všetky d’alšie protižidovské opatrenia, Körper nechápal ako výzvu na uponáhlané kroky, ktoré by mohli ohrozit' existenciu Slovákov, vraj ekonomicky závislých od Židov. Napriek tomu mal dôvod na oslavu: „Ideme v ústrety naozaj krásnej budúcnosti. Čoskoro celá pôda pod Tatrami bude v rukách slovenských, čoskoro obchody a podniky budú slovenské, tak ako to spravodlivost' požaduje. My si ani predstavit' nemôžeme, ako to bolo možné, že v tejto čisto slovenskej krajine hospodársky a obchodný život opanovali cudzinci. [...] Ani Nemci na tom neboli lepšie ako my. Aj tých opanovala cudzia rasa. ${ }^{\prime 71}$ Židovský zákon bol vraj v Československej republike nemyslitel'ný, ked’že sa nachádzala v područí slobodomurárov a bol'ševikov, ktorí boli podla Körperovho konšpiračného myslenia obyčajnými agentmi Židov. Ich panstvo sa však končí, Slováci im názorne, rukolapne ukážu, že ich vykoristovanie nebudú viac trpiet:: „Teraz už máme nielen oči otvorené, ale aj ústa. Naše ruky a päste sa už vol'ne pohybujú. Zariad'ujeme slovenský štát."72

Karol Körper koncom roku 1939 síce prestal písat’ úvodníky do Slovenskej pravdy, no agresívny antisemitizmus charakterizoval prinajmenšom niektoré z jeho rozhlasových prejavov pre príslušníkov Hlinkovej gardy. ${ }^{73}$ Záznamy týchto meditácií sa nedochovali, čast’ z nich však vychádzala ako stípčeky v tlačovom orgáne Hlinkovej gardy. Krestanstvo sa tu mení na heroické náboženstvo a Ježiš Kristus na mužného hrdinu bojujúceho proti náboženskému a národnému rozkladu stelesňovanému údajne Židmi - nielen obrazne povedané - so zbraňou v ruke. $V$ jednej zo svojich rozhlasových kázní hlavný duchovný správca Hlinkovej gardy uvažuje o tom, ako Ježiš vyhnal z chrámu židovských kupcov, údajné stelesnenie materializmu a cudzopasníctva. Jeho meditácia vygradovala do nemeckého propagandistického hesla o Židoch ako "neštastí iných národov: „Vo svojom spravodlivom hneve a vo svojej svätej rozhorčenosti pustil sa ináč tak jemný Ježiš do predavačov a kupcov, ktorí pred chrámom robili svoje obchody a vyhnal ich od svätyne Božej. [...] Kristus mnoho trpel a pretrpel. Ked' raz v živote svojom predsa chytá do ruky bič a šlahne ním po l'ud'och, tak to museli byt'opravdu l'udia, ktorí sú nešt'astím ostatných l'udí na svete. ${ }^{\prime 74}$ Karol Körper sa tu snažil sprostredkovat' gardistom, ktorých mal v duchovnej opatere, predstavu o militantnom spasitelovi, ktorého predobraz na prelome

70 Dr. k. k. Lekár. In Slovenská pravda, roč. 4, č. 172, 29. júla 1939, s. 1.

71 Dr. k. k. Židovský zákon. In Slovenská pravda, roč. 4, č. 92, 21. apríla 1939, s. 1.

72 Tamže.

73 Vo svojich spomienkach sa Körper usiluje zbavit’ zodpovednosti aj za tieto prejavy - príznačne apelovaním na antikomunizmus a podsúvaním fašizmu svojim oponentom: „Aká nehorázna zlomysel'nost' a hlúpost' to bola, že neskôr pri národnom súde kvalifikovali túto našu činnost' ako »fašistickú". To mohli robit' iba servilní l'udia metódami zhubného stalinizmu fašistického rázu, tí, čo v časoch d'alšej deformácie vešali aj idealistov - komunistov." KÖRPER-ZRÍNSKY 1993, s. 155.

74 KÖRPER, Karol. Gardista - vyháňač kupcov. In Gardista, roč. 2, č. 28, 12. júla 1940, s. 2. 
19. a 20. storočia načrtol iný slovenský kňaz, Andrej Rojko, podla ktorého bol Ježiš Kristus „prvým antisemitom ". ${ }^{4}$

Po salzburských rokovaniach v roku 1940 Karol Körper upadol do nemilosti nacistického poradcu pre Hlinkovu gardu Viktora Nagelera a „židovskej otázke“ sa už v prejavoch ani publicistike nevenoval. Pred Národným súdom tvrdil, že si bol dobre vedomý rozporov vyplývajúcich z jeho poslaneckých povinností - na otázku sudcu, prečo neabdikoval, odpovedal, že vo funkcii zostal na výslovné želanie biskupa Jozefa Čárskeho. Tieto rozpory sa Körper pokúšal riešit’ tak, že počas hlasovania o zákone o deportáciách v máji 1942 (vo výpovedi mylne uvádza o „rasových zákonoch“ - tie sa však neprijímali v parlamente) „sme [Eugen] Filkorn, ja a ešte niekto odišli." ${ }^{\text {“76 }}$ Hlavným argumentom však mala byt' jeho pomoc „rasove prenasledovaným“. Körper v povojnových spomienkach opisuje, ako vraj v roku 1942 osobne zaviedol nuncia Giuseppe Burzia k prezidentovi Tisovi, pripisujúc si tým nemalé zásluhy: „Tomuto zákroku možno d'akovat' za rozhodnutie vlády zastavit' transporty Židov do Nemecka a zriadit' pre nich osobitné tábory na Slovensku. ${ }^{177}$

Hoci na účely obhajoby pred Národným súdom Karol Körper zhromaždil väčší počet svedectiev o svojej úlohe pri záchrane slovenských Židov, niekdajšiu ideologickú zaujatost' napriek tomu neprekonal, čo dokazujú práve jeho spomienky. Ako záchranca Židov bol vraj Körper natol'ko známy a uznávaný, že „nejakí vplyvní Židia“ mu navrhli, že ho unesú a „prepašujú do zahraničia“ ${ }^{78}$ Körper bol však natol'ko presvedčený o svojej nevine, že tento návrh odmietol. Aby vyvrátil podozrenia z rasistického antisemitizmu, Körper na inom mieste uvádza príklad spoluväzňa, mladého krajčírskeho učňa, u ktorého váhal, „či je Žid alebo Cigán“. ${ }^{79}$ Učeň Körperovi prišiel na pomoc a sám tú „záhadu“ drasticky vysvetlil: „Moja matka bola hluchonemá slabomysel'ná Cigánka. Istý Žid, ktorý zbieral kožky, ju za dvadsat' korún zneužil. Tak som prišiel na svet. ${ }^{\text {(80 }}$ Körper ho nezatracoval, naopak, tíšil jeho smäd po katechizme. Napriek tomu ešte $\mathrm{v}$ 60. rokoch minulého storočia znovu a znovu podliehal starým stereotypom. Spomínal si napríklad na skupinu Židov, „ktorí sa vrátili z emigrácie, kde sa im dobre vodilo" a dostali sa na vysoké posty. ${ }^{81}$ Tí sa vraj vyžívali v utrpení väzňov, hoci ich zakrátko stihol ešte horší osud.

Körperov prípad ukazuje, že kontinuálna antisemitská propaganda v okruhu HSL'S neprepukla zo dňa na deň po vyhlásení autonómie na jeseň 1938, hoci od tohto momentu sa výrazne radikalizovala. Vyvíjala a prehlbovala sa minimálne od roku 1936, najskôr ako polemika proti „židobol'ševizmu“ a postupne aj v podobe úvah o „riešení židovskej otázky". Popri čisto propagandistických iniciatívach treba zdôraznit’ systematické návrhy usilujúce o diskrimináciu Židov na sociálnoekonomickom, ale už

75 SZABÓ 2018, s. 43.

76 SNA, f. NS, Tnlud 17/45, Stenogram z hlavného rokovania Nár. súdu s obžalovaným Dr. Körperom.

77 KÖRPER-ZRÍNSKY 1993, s. 159.

78 Tamže, s. 199.

79 Tamže, s. 192.

80 Tamže.

81 Tamže, s. 217. 
aj etnickom základe, hoci bol pojem Žid definovaný ešte nedôsledne kombináciou náboženských a rasistických kritérií. L'udácky antisemitizmus sa napokon rozvíjal v domácom i medzinárodnom kontexte, pričom referenčným bodom nebolo výlučne nacistické Nemecko, ba ani stredná Európa, ked’že Karol Körper sa k rasizmu zjavne priklonil až v USA. Všetky tieto tendencie potvrdzujú oprávnenost' a opodstatnenost' výskumu antisemitizmu na medzivojnovom Slovensku, ktorý je stále iba na začiatku.

\section{Cituj:}

SZABÓ, Miloslav. Od kampaní proti „židobol’ševizmu“ k návrhom na „riešenie židovskej otázky“. Antisemitizmus v publicistike Karola Körpera v druhej polovici 30. rokov 20. storočia. In Forum Historiae, 2019, roč. 13, č. 1, s. 57-74. ISSN 1337-6861. DOI: https://doi.org/10.31577/ forhist.2019.13.1.5

...

Mgr. Miloslav Szabó, PhD.

Katedra germanistiky, nederlandistiky a

škandinavistiky

Univerzita Komenského v Bratislave

Gondova ul. 2, P.O. BOX 32

81499 Bratislava

Slovenská republika

miloslav.szabo@uniba.sk 